Marquette University

e-Publications@Marquette

College of Education Faculty Research and

Publications

Education, College of

$1-1-2016$

\title{
Reflective Journaling: Fostering Dispositional Development in Preservice Teachers
}

Jeffrey LaBelle

Marquette University, jeffrey.labelle@marquette.edu

Gabrielle Belknap

Marquette University, gabrielle.belknap@marquette.edu

Accepted version. Reflective Practice Vol. 17, No. 2 (2016). DOI. (C) 2016 Taylor \& Francis

(Routledge). Used with permission. 


\title{
Reflective journaling: fostering dispositional development in preservice teachers
}

\author{
Jeffrey T. LaBelle \\ College of Education, Educational Policy and Leadership \\ Marquette University \\ Milwaukee, WI \\ Gabrielle Belknap \\ College of Education, Educational Policy and Leadership \\ Marquette University \\ Milwaukee, WI
}

\section{Background}

Many undergraduate preservice teacher preparation programs at Catholic colleges and universities in the U.S. require candidates to take courses in philosophy (Mucci \& Cranston-Gingras, 2011). Among these, some institutions include a free-standing philosophy of education course as an essential part of their preservice teacher requirements. In reviewing the motivations and purposes for requiring a separate course in the philosophy of education, one finds great variation. For example, Gosselin (2007) emphasized the importance of philosophy of education courses for preservice teachers because 'they typically do not understand how philosophy of education fits into the grand narrative of philosophy as a discipline' (p. 42). On the other

Reflective Practice, Vol 17, No. 2 (February 16, 2016): pg. 125-142. DOI. This article is (C) Taylor \& Francis (Routledge) and permission has been granted for this version to appear in e-Publications@Marquette. Taylor \& Francis (Routledge) does not grant permission for this article to be further copied/distributed or hosted elsewhere without the express permission from Taylor \& Francis (Routledge). 
hand, Mucci and Cranston-Gingras (2011) made the case for such courses by asserting that 'Philosophy courses pertaining to philosophy of education allow preservice teachers to begin to examine their own goals for teaching and how those goals will be accomplished through specific teaching methods' (p. 386). In this study, we contend that the philosophy of education can help teacher candidates examine how their own knowledge, skills, and dispositions influence their behaviors and why they make certain decisions regarding their curriculum and teaching methodology.

Regardless of the purported reasons for requiring preservice teachers to take courses in the philosophy of education, most Catholic institutions seek to develop critical or reflective thinking skills throughout their preservice teacher programs. To that same end, past research has pointed to the importance of developing dispositions in preservice teachers through reflecting writing and journaling (Freese, 1999, 2006; Oner \& Adadan, 2011; Schussler, Stooksberry, \& Bercaw, 2010; Zeichner \& Liston, 1996). In fact, even more recently, the Council for the Accreditation of Educator Preparation (CAEP, 2013) has recommended '....additional research to define professional practices of P-12 educators and how these practices, beliefs, and attitudes relate to student learning and development' (p. 12).

Because philosophy of education courses might provide an excellent platform for promoting reflecting journaling as a means of disposition development in preservice teachers, we posed the following research questions:

1) Does reflective journaling help promote dispositional development in preservice teachers?

2) What types of dispositions do preservice teachers self-identify in their reflective journaling?

In order to examine this potential contribution to dispositional development in preservice teachers, we examined preservice teacher journaling in a semester-long philosophy of education course across five semesters and seven different class sections of students enrolled in our preservice teacher program (See Table 1). Each of the five journaling tasks had a specific prompt (see Appendix) and yielded a total of five, 500-word reflective essays for each candidate. Preservice teachers take this course toward the end of the program, just prior to

Reflective Practice, Vol 17, No. 2 (February 16, 2016): pg. 125-142. DOI. This article is (C) Taylor \& Francis (Routledge) and permission has been granted for this version to appear in e-Publications@Marquette. Taylor \& Francis (Routledge) does not grant permission for this article to be further copied/distributed or hosted elsewhere without the express permission from Taylor \& Francis (Routledge). 
full-time student teaching. It is noteworthy that they have already had a great deal of field experience in schools in urban settings with a wide-range of ethnic and racial diversity.

Table 1 Reflective Journaling Samples by Class Section

\begin{tabular}{|c|c|c|c|c|}
\hline Course & Semester & Year & \# journals & \# students \\
\hline EDUC 158 & spring & 2009 & 4 & 19 \\
\hline EDUC 4540-701 & fall & 2009 & 5 & 40 \\
\hline EDUC 4540-701 & spring & 2010 & 5 & 33 \\
\hline EDUC 4540-102 & fall & 2010 & 5 & 19 \\
\hline EDUC 4540-701 & fall & 2010 & 5 & 18 \\
\hline EDUC 4540-701 & spring & 2011 & 5 & 27 \\
\hline EDUC 4540-102 & spring & 2011 & 5 & 24 \\
\hline EDUC 4540-701 & spring & 2012 & 5 & 22 \\
\hline
\end{tabular}

\section{Review of Related Literature}

Essential to this study are several concepts which have rather lengthy historical developments and which researchers frequently operationalize with diverse connotations. We examined the following four concepts regarding the preparation of teachers for the profession: 1) dispositions, 2) reflection, 3) reflecting thinking, and 4) reflective journaling.

Dispositions. Teacher dispositions are elaborately developed in the Interstate Teachers Assessment and Support Consortium (InTASC) Standards for Teacher Development and Licensure (2011), in which dispositions form one of three types of indicators essential to achieve each standard or principle. Hence, besides knowledge and performances, the InTASC standards obligate preservice teacher programs to develop and foster certain dispositions in their candidates. Particularly pertinent to this study is the list of dispositions noted under 'Reflective Practice: Professional Growth - Principle 9: The teacher is a reflective practitioner who continually evaluates the effects of his/her choices and actions on others (students, parents, and other professionals in the learning community) and who actively seeks out opportunities to grow professionally' (InTASC, 2011, p. 10). More recently, the CAEP (2013) fully endorsed these same InTASC standards in its own Standard 1, pointing out that these standards as well as 'the performances, knowledge and dispositions that are extensions of those standards contain literally scores of references to

Reflective Practice, Vol 17, No. 2 (February 16, 2016): pg. 125-142. DOI. This article is (C) Taylor \& Francis (Routledge) and permission has been granted for this version to appear in e-Publications@Marquette. Taylor \& Francis (Routledge) does not grant permission for this article to be further copied/distributed or hosted elsewhere without the express permission from Taylor \& Francis (Routledge). 
cultural competence, individual differences, creativity and innovation and working with families and communities (CAEP, 2013, p. 21).'

Although the CAEP introduced the concept of attributes into its accreditation standards, the Council chose to keep the language of the InTASC standards intact throughout its 2013 document, especially in regard to knowledge, skills, and dispositions. In fact, in the description of Additional Selectivity Factors in CAEP Standard 3, we found the following description:

3.3 Educator preparation providers establish and monitor attributes and dispositions beyond academic ability that candidates must demonstrate at admissions and during the program. The provider selects criteria, describes the measures used and evidence of the reliability and validity of those measures, and reports data that show how the academic and non-academic factors predict candidate performance in the program and effective teaching. (CAEP, 2013, p. 9)

Hence, even in the discussion of candidate selection in CAEP Standard 3 , we discovered the intermingling of terminology, such as attributes and dispositions. This varying use of terminology additionally suggests the need to further explore the conceptualization of dispositions since they continue to be an essential part of the standards for teacher preparation in the light of the CAEP accreditation standards. In fact, the word 'disposition(s)' is used 18 times in the CAEP (2013) document, in sharp contrast to 4 usages of the term 'attribute(s).'

A review of related literature pointed to an extended historical debate (Borko, Liston, \& Whitcomb, 2007; Burant, Chubbuck, \& Whipp, 2007; Damon, 2007; Diez, 2007; Sockett, 2006; Socket, 2009; Villegas, 2007) in pursuit of an operational definition of dispositions. This debate hinged on a wide variation in theoretic frameworks including psychology, sociology, ethics, and finally philosophy. Depending upon the hermeneutical or heuristic approach of the researcher, the term dispositions took on different meanings and, consequently, was operationalized differently in each preservice teacher program. 
NOT THE PUBLISHED VERSION; this is the author's final, peer-reviewed manuscript. The published version may be accessed by following the link in the citation at the bottom of the page.

Accepting Chubbuck's (2010) conceptualization of dispositions, one can settle upon the construct developed by the National Council for Accreditation of Teacher Education (NCATE) of fairness and the belief that all students can learn as the two key dispositions of a qualified teacher. NCATE (2008) defined professional dispositions as 'Professional attitudes, values, and beliefs demonstrated through both verbal and non-verbal behaviors as educators interact with students, families, colleagues, and communities' ( $p .89$ ). NCATE expected IHEs to assess for these types of behaviors as well as the two central dispositions mentioned by observation in actual educational contexts. In addition, NCATE permitted IHEs, 'based on their mission and conceptual framework...[to] identify, define, and operationalize additional professional dispositions' (p. 90).

However, it is worth noting that, in contrast to this definition, Sockett's (2006) three-part definition, character, intellect, and care, presented quite an appealing and compelling argument. These three qualities are explicitly ethical in nature, but entail additional attributes that have measurable behaviors associated with each of them. Diez (2007) summarized the ethical or moral nature of these dispositions: 'In a very thoughtful essay, Sockett (2006) sets the discussion of dispositions firmly in the context of moral education, outlining three different philosophical perspectives-character, rules, and relations' (Diez, 2007, pp. 390-391). In his original article, Sockett (2006, pp. 17-18) elucidated more elaborately the nature of these three types of primary dispositions:

1) character: 'integrity in the context of wisdom, courage, temperance, and justice'

2) intellect: 'wisdom, consistency (in the application of rules), fairness and impartiality (from the principle of justice), and open-mindedness in the consideration of rule when the ethics of rules is rooted in justice'

3) care: 'receptivity, relatedness, and responsiveness in the context of the creation of trust'

Both Diez's (2007) and Sockett's (2006) analyses pointed to a much broader definition of disposition than NCATE's (2009) elaboration of dispositions among preservice teachers. These earlier conceptualizations provided the groundwork for the present study

Reflective Practice, Vol 17, No. 2 (February 16, 2016): pg. 125-142. DOI. This article is (C) Taylor \& Francis (Routledge) and permission has been granted for this version to appear in e-Publications@Marquette. Taylor \& Francis (Routledge) does not grant permission for this article to be further copied/distributed or hosted elsewhere without the express permission from Taylor \& Francis (Routledge). 
because they suggested other attributes or values that go beyond the scope and range of the two dispositions, fairness and the belief that all students can learn (NCATE, 2008).

To that end, NCATE's own (2006) findings distinguished between dispositions per se and other guiding elements such as 'beliefs and attitudes related to values such as caring, fairness, honesty, responsibility and social justice' (NCATE, 2006, p. 53). Hence, at that time NCATE (2006) defined dispositions as 'The values, commitments, and professional ethics that influence behaviors towards students, families, colleagues, and communities, and affect student learning, motivation, and development as well as the educator's own professional development' (p. 53). Even more telling was NCATE's reference to examples of a broader array of dispositions including '...a vision of high and challenging standards, or a commitment to a safe and supportive learning environment' (p. 53).

Our research investigated NCATE's (2008) two identified dispositions for all preservice teachers, as well as those self-identified dispositions (that is, those spontaneously named by individuals in their reflective journaling) that are closely associated with NCATE's essential two dispositions, yet often represent a set of values, commitments, and professional ethics that are more complex and extremely nuanced in narration.

Recently the CAEP (which assumed the accreditation responsibilities for NCATE on July 1,2013 ) recognized these same complexities and challenges to preservice teacher preparation. In addition, the Council pointed to further areas of research that are needed regarding dispositions when they asserted, 'Research has not empirically established a particular set of non-academic qualities that teachers should possess...The Commission recognizes the InTASC standards' set of dispositions as a promising area of research' (CAEP, 2013, p. 11).

Reflection. Educational theorists and researchers have employed this term quite broadly (Clarà, 2015) and hence it needs to be carefully operationalized if a researcher is to accurately interpret the qualitative data coded and analyzed in preservice teacher

Reflective Practice, Vol 17, No. 2 (February 16, 2016): pg. 125-142. DOI. This article is (C) Taylor \& Francis (Routledge) and permission has been granted for this version to appear in e-Publications@Marquette. Taylor \& Francis (Routledge) does not grant permission for this article to be further copied/distributed or hosted elsewhere without the express permission from Taylor \& Francis (Routledge) 
journaling. In their careful review of the literature on reflection, Oner and Adadan (2011) observed that 'The notion of reflection is ubiquitous in teacher education literature, yet its meanings differwhich perhaps signifies the difficulties of making the construct operational' (p. 479). Hatton and Smith (1995), Korthagen and Wubbels (1996), and others set the stage for looking at reflection as a concept. In support of the importance of linking reflection to practice, Loughran (2002) asserted, 'For reflection to lead to valuable learning outcomes for teacher educators and their students, I believe it must be effective reflective practice' (p. 33). However, this distinction would then require further clarification since what one intends by effective is quite subjective. After carefully reviewing the wide variation and challenge in defining reflection, we concur with Oner and Adadan's (2011) conclusion that 'In this study, reflection tasks are designed for the ultimate purpose of transforming our participants' action (i.e., their teaching)' (p. 480).

Reflective thinking. Still other theorists have approached reflection as one type of thinking or reasoning process in the learner. For example, Dewey (1974), Rodgers (2002), and Zeichner and Liston (1996) studied the benefits of reflective thinking in education. Dewey quite early (1916) elaborated on the reflective process in detail when he stated:

There are many words to represent the reflective process: debrief, process, consider, ponder, weigh, analyze, and evaluate are just a few. While each of these terms varies slightly in meaning, they all include some core elements. First, reflection is a deliberate thinking process applied to an experience, idea, or issue. Second, reflection takes time and the more time we can devote to it, the greater potential for learning and insight. Third, reflection can lead to cognitive growth resulting in new understandings and appreciations. Finally, reflection is an ethical undertaking in the sense that it should inform our future actions. (Dewey, 1916, as cited by Wade, 1996, p. 64)

More recently Larrivee (2000) borrowed from Dewey's analysis of reflective thinking when he stated, 'The dissonance created in understanding that a problem exists engages the reflective thinker to become an active inquirer, involved both in the critique of current conclusions and the generation of new hypotheses' (p. 294). This 
process of active inquiry is the compelling force that moves the preservice teacher from theory to practice and their interrelationship. As Larrivee (2000) further argues, 'Engaging in critical reflection brings commonly-held beliefs into question' (p. 295). Even more recently, new methodologies such as Ghaye et al.'s (2008) Participatory and Appreciative Action and Reflection (PAAR) have carried critical thinking into the realm of action research for the purpose of democratizing reflective processes.

Reflective journaling. Much discussion appeared in the literature regarding teacher portfolios and how they affect dispositions. Borko et al. (1997), Oner and Adadan (2011), and others view reflective writing, often a required component in preservice teacher portfolios, as an essential tool in their dispositional and attitudinal development. Such reflective writing or journaling can lead to changes in performance in fieldwork. Indeed, Smyth (1999) concluded that if teachers (and teacher educators) are going to uncover the forces that inhibit and constrain them, they need to engage in four forms of action with respect to teaching. These 'forms' were characterized by four sequential stages and were linked to a series of questions: (a) describing (What do I do?), (b) informing (What does this mean?), (c) confronting (How did I come to be like this?), and (d) reconstructing (How might I do things differently?). Again, Larrivee (2000) succinctly captured what is crucial in this regard when he asserted, 'Reflective practitioners challenge assumptions and question existing practices, thereby continuously accessing [a] new lens to view their practice and alter their perspectives' (p. 296). Furthermore, Pedro (2005) recognized the cultural responsiveness of such reflective thinking when he acknowledged '...the reflective practice paradigm as another way to help teachers learn how to accommodate the diverse needs of their students' (p. 50).

Part of the challenge to teacher education faculty members is how to understand the cognitive and reflective process that the preservice teachers are undergoing. One possibility is to read their narratives or reflective journaling to listen to their own description of this process. As Pedro (2005) went on to explicate:

I believed that looking at reflection through the eyes of the preservice teachers would greatly add to my understanding of

Reflective Practice, Vol 17, No. 2 (February 16, 2016): pg. 125-142. DOI. This article is (C) Taylor \& Francis (Routledge) and permission has been granted for this version to appear in e-Publications@Marquette. Taylor \& Francis (Routledge) does not grant permission for this article to be further copied/distributed or hosted elsewhere without the express permission from Taylor \& Francis (Routledge). 
reflective practice... insights gained from such a process would allow me to more ably assist pre-service teachers to get a strong start on their practice. (p. 50)

Russell (2005) concurred with the importance of entering the preservice teachers' worlds when he called for fostering such reflective practices as journaling that is intentional and guided:

'I now believe that reflective practice can and should be taughtexplicitly, directly, thoughtfully and patiently-using personal reflection-in-action to interpret and improve one's teaching of reflective practice to others' (pp. 203-204). Based upon Russell's (2005) recommendation that, 'Further research on strategies for teaching reflective practice should prove valuable for professional educators' (p. 204), we conducted the present study to review our implementation of such reflective practice to foster disposition development among preservice teachers.

\section{Method}

Although our study of reflective journaling entailed some quantitative elements, such as counting the frequency of recurring themes, this study primarily employed a qualitative methodology. Bogdan and Biklen (1998) described this type of research, 'While their use as an auxiliary is most common, increasingly, qualitative researchers are turning to documents as their primary source of data' (p. 57). To that end, the primary sources of our research data were personal documents. As Bogdan and Biklen (1998) have stated, 'In most traditions of qualitative research, the phrase personal documents is used broadly to refer to any first-person narrative that describes an individual's actions, experiences, and beliefs' (p. 134). Their lived experiences as preservice teachers, as well as their academic reading and study, provide the basis for their reflective journaling.

In particular we were interested in the preservice teachers' own perspectives on their dispositions, that is, their self-identified dispositions as future educators. Because of this, our coding centered on the preservice teachers' reflective thinking as exhibited in journal entries. We used what Lieblich, Tuval-Mashiach, and Zibler (1998) call 'Categorical-Content' analysis (p. 13). This method of narrative analysis, focuses on reading across the stories to find common

Reflective Practice, Vol 17, No. 2 (February 16, 2016): pg. 125-142. DOI. This article is (C) Taylor \& Francis (Routledge) and permission has been granted for this version to appear in e-Publications@Marquette. Taylor \& Francis (Routledge) does not grant permission for this article to be further copied/distributed or hosted elsewhere without the express permission from Taylor \& Francis (Routledge). 
themes. In this form of analysis, 'categories of the studied topic are defined, and separate utterances of the text are extracted, classified, and gathered into these categories/groups' (Lieblich et al., 1998, p. 13). Furthermore, our coding identified rich, descriptive language that gives voice to the participants' perspectives as preservice teachers.

In order to codify and document preservice teacher dispositions, we collected journaling from each class section. These narratives were electronic documents students had uploaded to the course Desire2Learn (D2L) site for each semester to form the corpus of content examined. We protected students' identities sufficiently by blinding their names and student identification numbers and then assigning a random number to each document. This corpus of reflective journaling represents the cumulative writing of preservice teachers (not students from other majors or disciplines), spanning three academic years and seven separate sections of students, for a total population of 183 participants (see Table 1 ). We designed a qualitative coding instrument to identify recurring themes and emerging dispositional changes in each individual and within each class section. To verify the coding instrument's reliability to identify perceived dispositions throughout the semester, we conducted a pilot study of a previous section of the same course not included in the corpus of reflective journaling in this study, but which represents similar types of journaling prompts (Appendix) and expected learning outcomes.

Prior to coding the reflective journaling of the sample population, we met to review the results of the pilot study of a sampling of reflective journals for the NCATE dispositions. The coding consisted of underlining key words or phrases and then marking either ' $F$ ' or ' $B$ ' in the margin to indicate examples of the NCATE dispositions, fairness ('F') and belief that all students can learn ('B'). In addition to reviewing the findings of the pilot study, we discussed any concerns, questions, or difficulties encountered to ensure intercoder reliability. We reviewed the hand-written markings of frequency counts for each coded item, tallied the frequencies mathematically, and determined that the four sets of reflective journaling resulted in differences in the frequency of self-identified dispositions. This methodology is consistent with Lieblich et al. (1998), who state that content analysis

Reflective Practice, Vol 17, No. 2 (February 16, 2016): pg. 125-142. DOI. This article is (C) Taylor \& Francis (Routledge) and permission has been granted for this version to appear in e-Publications@Marquette. Taylor \& Francis (Routledge) does not grant permission for this article to be further copied/distributed or hosted elsewhere without the express permission from Taylor \& Francis (Routledge). 
often lends itself to making statements in narratives quantifiable. Based upon these numerical data, we concluded the following: Journal 1: A good number of examples of both $F$ and $B$ (13 and 9 respectively); Journal 2: many examples of $F(14)$, very few of $B(2)$; Journal 3: many $F(10)$, no B (0); and Journal 4: many $F(15)$, few B (4).

During our discussion and review of the frequency of coded items to ensure intercoder reliability, we posed two questions which in essence identified the limitations of the study: How can one separate the topic or content for a particular reflective journaling assignment from self-identified preservice teacher dispositions? To what extent did the particular prompt (see Appendix) for a reflective journaling assignment influence self-reflection on fairness or belief that all students can learn? Responses to these two questions will be taken up later in the data analysis section.

Since the literature was not specific about how to identify these two NCATE dispositions, we struggled to identify indicators appropriate to each. During our experience of coding in the pilot study, we both observed other themes that recurred in the reflective journaling of preservice teachers. This suggested the need for the coding of the actual study to include not only notations for the two NCATE dispositions, but also several other themes that surfaced, especially in the last two journal assignments: openness, empowerment, caring, and relationships. As the later CAEP (2013) accreditation standards concluded (in discussing teacher effectiveness): 'These 'other' attributes, dispositions and abilities lend themselves to provider innovation. Some providers might emphasize certain attributes because of the employment field or market for which they are preparing teachers' (CAEP, 2013, p. 11).

Using the piloted coding instrument, we proceeded to code the seven class sections to determine recurring dispositional themes within each class section and among the seven class sections. These coded narrative data were then collated, categorized, and counted for frequency as well as for qualitative interpretation and discussion. In addition, other dispositions, such as, openness, empowerment, caring, 
and relationships, which preservice teachers self-identified, were noted for further analysis and discussion.

\section{Data Analysis}

In order to determine the frequency of self-identified dispositions as one means of responding to the first research question (Does reflective journaling help promote dispositional development in preservice teachers?), we counted the number of times we had coded student reflective journaling narratives for each of the three disposition categories, that is, 1) fairness, 2) belief that all students can learn, and 3) other (Table 2). The totals indicated in Table 2 are listed by class section, and represent the composite coding for all five journal entries within each class section. We noticed the great contrast between 65 frequencies for fairness in class section 1 and only 15 occurrences in class section 6 . In part this is due to the number of preservice teachers enrolled in those particular sections, 40 for class section 1 and 24 students in class section 6 . Nevertheless, in spite of this variation in the frequencies of coded dispositions between class sections, the overarching trend indicates a much larger frequency of self-identified fairness (233 occurrences) in contrast to the belief that all students can learn (53 occurrences). Furthermore, a great number of preservice teachers self-identified other dispositions (139 occurrences), which we examine later in this article.

Table 2 Frequency of Self-Identified Dispositions

\begin{tabular}{|c|c|c|c|c|}
\hline Section & $\mathbf{N}$ & Fairness & Belief That All Students Can Learn & Other \\
\hline 1 & 40 & 65 & 17 & 28 \\
\hline 2 & 33 & 25 & 5 & 21 \\
\hline 3 & 19 & 31 & 5 & 17 \\
\hline 4 & 18 & 34 & 9 & 27 \\
\hline 5 & 27 & 24 & 4 & 12 \\
\hline 6 & 24 & 15 & 3 & 14 \\
\hline 7 & 22 & 29 & 10 & 20 \\
\hline Total & $\mathbf{1 8 3}$ & $\mathbf{2 2 3}$ & $\mathbf{5 3}$ & $\mathbf{1 3 9}$ \\
\hline
\end{tabular}

As pointed out previously, one clear limitation of this study was the influence that the instructor's prompt held for each journal entry (see Appendix). These prompts were intended to focus the candidates'

Reflective Practice, Vol 17, No. 2 (February 16, 2016): pg. 125-142. DOI. This article is (C) Taylor \& Francis (Routledge) and permission has been granted for this version to appear in e-Publications@Marquette. Taylor \& Francis (Routledge) does not grant permission for this article to be further copied/distributed or hosted elsewhere without the express permission from Taylor \& Francis (Routledge). 
attention on a particular theme and encourage reflective thinking, but they may also have encouraged the preservice teachers into narrating particular dispositions appropriate to their reading or the prompt itself. In spite of this apparent limitation, each prompt still succeeded in promoting a great deal of reflective thinking and, indirectly, the selfidentification and clarification of their perceived dispositions. In more particular terms, the breadth of themes generated the prompts' focus on a particular topic might have coerced the participant into responding with particular thematic content. Even so, we contend that any changes, emphases, or apparent growth in the depth of the reflective thinking among the preservice teachers are worth noting.

Obviously one cannot generalize the results of this study to all preservice teachers who engage in reflective journaling or participate in a philosophy of education course. However, the results suggest a value-added dimension of such free-standing philosophy of education courses in preservice teacher programs. Another limitation is the particular mission and vision of the program and its overarching mission as a Jesuit, Catholic institution of higher education with all its other demographic peculiarities, e.g., regional culture, national university status, local educational landscape (choice, vouchers, charter schools). We also note that the results of this study are limited to the self-identified dispositions coded and are influenced by the whims of the emerging adults' perceptions and the attitudinal, as well as value and moral, changes of the preservice teachers.

In their study of philosophy courses at Catholic colleges and universities, Mucci and Cranston-Gingras (2011) concluded that these courses, '...afford preservice teachers the opportunity to begin to know the self with regard to understanding their capacities and what makes them human beings as well as allowing them to be in touch with who they are in the world' (p. 388). The data we present here reaffirm Mucci's and Cranston-Gingras's (2011) findings in regard to the required philosophy of education course at one Catholic university. Even though the scope of their study included all philosophy requirements, and not just philosophy of education requirements, Mucci and Cranston-Gingras (2011) went on to claim that through this coursework, '...preservice teachers learn to see themselves as thinking beings with a responsibility to question and reflect on their own values permission has been granted for this version to appear in e-Publications@ Marquette. Taylor \& Francis (Routledge) does not grant permission for this article to be further copied/distributed or hosted elsewhere without the express permission from Taylor \& Francis (Routledge). 
and beliefs as they make critical decisions affecting the lives of future generations of children' (p. 389). Clearly this questioning and reflecting on values and beliefs is an essential part of any preservice teacher program and leads to changes in pedagogical practice if successfully appropriated by the preservice teacher (Chubbuck, 2010). We posit that such reflective thinking often leads teacher candidates to examine themselves more deeply and identify additional dispositions beyond fairness and the belief that all students can learn. These additional dispositions might form part of those identified as central to the particular mission of the institution of higher education as allowed in the NCATE (2008) definition of professional dispositions cited previously, 'Based on their mission and conceptual framework, professional education units can identify, define, and operationalize additional professional dispositions' (p. 90).

Having sufficiently analyzed and discussed the significance of the frequency data, we now will discuss and analyze the qualitative data found in the personal documents, that is, the reflective journaling narratives themselves. These narratives respond to the second research question: What types of dispositions do preservice teachers self-identify in their reflective journaling? Here one can see recurring themes and trends across class sections, among students, and across semesters. The first two themes are the official NCATE (2008) professional dispositions of fairness and the belief that all students can learn. After reviewing the data regarding these two themes, we then will analyze other dispositional themes that emerged. These include 1) critical thinking, 2) caring, 3) openness, 4) moral education, and 5) individual freedom.

Fairness. Although many preservice teachers chose to selfidentify fairness as one of their dispositions (233 occurrences), a close examination of their narratives uncovers a wide variation in their interpretations of what fairness means in practice. NCATE (2008) defined fairness as, 'The commitment demonstrated in striving to meet the educational needs of all students in a caring, non-discriminatory, and equitable manner' (p. 86). In fact, we realized that we could best divide the reflective journaling coded for fairness as a self-identified disposition into four subcategories: 1) fairness as inclusion of all socioeconomic classes and abilities, 2) fairness through culturally permission has been granted for this version to appear in e-Publications@Marquette. Taylor \& Francis (Routledge) does not grant permission for this article to be further copied/distributed or hosted elsewhere without the express permission from Taylor \& Francis (Routledge). 
responsive teaching, 3) fairness through differentiation of instruction, and 4) fairness through fostering a safe learning environment. In the following section we analyze statements made by the preservice teachers themselves to illustrate the rich variation in their understanding and identification of fairness as a professional disposition.

\section{Fairness as inclusion of all socioeconomic classes and abilities.}

Much as Chubbuck (2010) discovered in her analysis of preservice teachers, some participants viewed fairness in terms of its social justice implications. One candidate commented, 'I will never let a child's social economic status reflect how smart I think they are and how I will teach them in my classroom.' In regard to the ability level of future students, another preservice teacher narrated, 'I will help each student develop themselves as human beings and make them see how they are talented and gifted, regardless of what a test score shows of them.' Finally, carrying the goal of teaching for social justice a step further, yet another teacher candidate viewed fairness in this way:

As a future teacher I will attempt to implement a critical pedagogy based on exploring curriculum from the social classes and backgrounds of my students. By doing this I will act to remove the inherent bias of my own beliefs and teach to the experiences of my students themselves.

\section{Fairness through culturally responsive teaching.}

Preservice teachers in this particular program are quite familiar with theorists who promote multicultural education, critical pedagogy, and culturally responsive pedagogy. Our candidates have read works by Banks and McGhee Banks (2010), Delpit (2006), Gay (2010), and Freire (2001). It is no surprise that some of our future educators would interpret fairness through these various lenses. For example, one preservice teacher described the vision of her future classroom:

In my classroom, I will exercise multicultural education practices to ensure that power is disbursed equally throughout my classroom, each child is given an opportunity to exercise their

Reflective Practice, Vol 17, No. 2 (February 16, 2016): pg. 125-142. DOI. This article is (C) Taylor \& Francis (Routledge) and permission has been granted for this version to appear in e-Publications@Marquette. Taylor \& Francis (Routledge) does not grant permission for this article to be further copied/distributed or hosted elsewhere without the express permission from Taylor \& Francis (Routledge). 
expertise or literacy in a subject of strength for them, and that knowledge is available to whoever wants it.

Another candidate saw one way to actualize her disposition to fairness through implementing a curriculum which would be inclusive of disenfranchised and disempowered groups. She wrote, 'Finally especially as a history teacher, I must set my curriculum to validate all ethnicities and historically marginalized groups.' Both of these are examples of dispositions which seek to be fair in culturally responding to the teaching and learning needs of diverse students.

\section{Fairness through differentiation of instruction.}

Because the philosophy of education course typically falls toward the last year of their course of study, some of the preservice teachers frequently identified fairness with differentiated instruction. The connections and applications the candidates make in their reflective journaling represent the influence of content knowledge and field placement experience over their first three years of formation as future educators. These profound connections between theory and practice are evident in the two comments we have selected as examples from those coded for fairness through differentiation of instruction. One preservice teacher commented from personal experience, 'We are all bound to teach in two ways: the way we were taught and/or the way we learn best.' Another teacher candidate concluded from both her experience and study, 'We must consistently strive to step beyond these comfort zones and create multiple ways students in our classes will learn and attain knowledge.'

\section{Fairness through fostering a safe learning environment.}

A more subtle, more nuanced interpretation of fairness is best phrased as a disposition to foster a safe learning environment. Clearly such efforts to ensure that students feel safe are essential in striving to achieve fairness in any other sense of the word. One preservice teacher viewed this as directly interconnected when she said, '...in order to ensure that the school is a safe haven for students who come from these conditions, teachers must exhibit tolerance and equality.' Another candidate perceived a need to develop a type of fairness that

Reflective Practice, Vol 17, No. 2 (February 16, 2016): pg. 125-142. DOI. This article is (C) Taylor \& Francis (Routledge) and permission has been granted for this version to appear in e-Publications@Marquette. Taylor \& Francis (Routledge) does not grant permission for this article to be further copied/distributed or hosted elsewhere without the express permission from Taylor \& Francis (Routledge). 
not only treats students equally but also recognizes the importance of other environmental factors:

Teachers need to be able to be open-minded and care about all of their students equally, schools need to provide opportunities for curriculum that is fair for all, and the communities (families, neighbors, etc.) need to support the students and the schools.

Finally, an additional future educator, clearly influenced by studying critical pedagogy, asserted, 'In my teaching, I will adhere to the theory that teacher and students are equal participants in the learning process in which ones' contributions are no more important than the other.' In all three of these examples, the candidates have interpreted fairness as going beyond their interaction with individual students to include the various social and environmental contexts which impact the feelings of well-being and security of their students.

Belief that all students can learn. To a lesser degree (53 occurrences among the 183 participants), the preservice teachers in this study chose to self-identify the belief that all students can learn as one of their dispositions. In this case, the participants shared similar interpretations of the meaning of this disposition which was given no specific definition in the NCATE (2008) document. Nevertheless, some noteworthy nuances are evident in the actual narratives themselves. For example, one candidate included the value of educating students in her comment, 'Actually, in order to teach effectively, I must instill the belief in my classroom that every student is worth educating.' Another preservice teacher included belief in herself as a learner in her comment, 'As far as the teacher is concerned, I believe we have the capacity to learn and grow just as much as our students in the classroom.' Finally a majority of the 53 coded comments pointed to the difficulties entailed in helping all students learn and the ramifications of such efforts from a social justice perspective. The following excerpt is quite representative of this development in the reflective journaling:

I plan to challenge every student, I understand that not all children are the same and that differentiated instruction is sometimes necessary, but I will never accept that some students are destined to end up in the lowest jobs and that I should not try to teach them beyond that.

Reflective Practice, Vol 17, No. 2 (February 16, 2016): pg. 125-142. DOI. This article is (C) Taylor \& Francis (Routledge) and permission has been granted for this version to appear in e-Publications@Marquette. Taylor \& Francis (Routledge) does not grant permission for this article to be further copied/distributed or hosted elsewhere without the express permission from Taylor \& Francis (Routledge). 
This concern or care for those who are disenfranchised or disempowered leads us to look more closely at some of the other dispositions generated by the preservice teachers in this study.

Other. Besides coding for fairness $(F)$ and belief that all students can learn (B), we also coded for other themes $(O)$ generated in the reflective journaling process. These other themes accounted for 139 instances of coding. We then further codified these other themes as critical thinking $(T)$, caring $(C)$, openness $(O)$, moral education $(M)$, and individual freedom (I).

\section{Critical thinking.}

Although some preservice teachers viewed the importance of critical thinking in terms of learner outcomes for their own students, quite a few stressed the importance of critical thinking for them as teachers. Others also pointed to the value of reflective writing as a tool to develop critical thinking skills. One preservice teacher wrote, 'The older I get, the more I realize that writing reflections, self-reflection and plain old reflections truly make a difference in how I live my life.' Even though some wrote about their future students, their writing indirectly indicates what the preservice teachers hold true for themselves also. For example, one wrote, 'By having students think critically, journal, and reflect on the material learned in the classroom and apply it to real life experiences out of the classroom, their knowledge is going to constantly be growing.' In general terms, the preservice teachers who identified critical thinking as a disposition in themselves or their students concurred that reflect journaling was a very useful medium to further this process.

\section{Caring.}

Most of the teacher candidates envisioned themselves as teachers who care for their students. Some have studied an ethic of caring (Mayeroff, 1971; Noddings, 1984) and wish to develop this disposition in themselves or recognize that this is one of their natural gifts. In fact, this desire might be attributed to the use of Noddings' (2012) text in the course and its resultant impact on the preservice teachers. Indeed, many indicated that caring was an essential

Reflective Practice, Vol 17, No. 2 (February 16, 2016): pg. 125-142. DOI. This article is (C) Taylor \& Francis (Routledge) and permission has been granted for this version to appear in e-Publications@ Marquette. Taylor \& Francis (Routledge) does not grant permission for this article to be further copied/distributed or hosted elsewhere without the express permission from Taylor \& Francis (Routledge). 
disposition for a successful teacher. One preservice teacher put it quite succinctly, 'Being a caring individual is essential to being a successful teacher.' Still other students developed what they intended by caring as a key attribute of a quality teacher. Another future educator elucidated, 'This caring enables a relating and understanding between those dialoguing; this develops empathetic, open-minded individuals who have made broad-based meaning and who are not closed-off to an alteration of that meaning.' Still others analyzed the effects of a caring disposition on their students' attitudes and performance. One analysis yielded the following statement: 'In showing that you care about what your students want to learn, an educator is more likely to keep the interest and attention of their students, as well as increase their performance when evaluating what they have learned.'

Clearly many of the preservice teachers in our study held the benefit of such caring in high esteem. They would concur with Irvine (2012) who surmised, 'Classroom interactions between teacher and students should be respectful and reflect genuine warmth and caring and sensitivity to students' cultures and levels of development' ( $p$. 271). Furthermore, the challenge of identifying and living out the disposition of caring is a daunting one. Van Manen (2000) made this quite clear when labeling the meaning of caring as a '...phenomenological puzzle [that] concerns the relation between...commonly accepted and professionally received meanings of the ethical concept of care as we find it in the parental, philosophical, and curriculum literature and...the lived experience of caring' (p. 315).

\section{Openness.}

Many preservice teachers identified the disposition of openness as an end in itself as well as a means to improving learning. 'I will make sure that no matter where I teach my students will know about all types of different cultures and understand how each of them can see the world differently and have different meanings for things.' In addition, some saw openness as leading into a more effective way of teaching or a more successful means for including children in the learning process, or even making them feel more welcome. 'I think it is important to create an atmosphere for all students to feel comfortable to be themselves in because when they are comfortable I

Reflective Practice, Vol 17, No. 2 (February 16, 2016): pg. 125-142. DOI. This article is @ Taylor \& Francis (Routledge) and permission has been granted for this version to appear in e-Publications@Marquette. Taylor \& Francis (Routledge) does not grant permission for this article to be further copied/distributed or hosted elsewhere without the express permission from Taylor \& Francis (Routledge). 
think it may be easiest for them to learn.' This type of openness is not unlike Dewey's (1974) concept of open-mindedness, which he viewed as an attitude that '...may be defined as freedom from prejudice, partisanship, and such other habits as close the mind and make it unwilling to consider new problems and entertain new ideas' (p. 224).

\section{Moral education.}

For many teacher candidates morality and ethics are rather contentious topics (Noddings, 2012). However, some of the preservice teachers in our study wrote about their role as a model of behavior for their students. For example, one participant ventured, 'I will be an ethical role model for my students and stimulate critical curiosity for all things in them.' Not only did this preservice teacher see her role as a moral one, but she further envisioned herself as engendering critical attitudes in her students through her demeanor and behavior. Other candidates looked at the social contexts of their future students as a consideration in regard to moral education. One of these opined, 'I think it is especially important for children to develop character at school because many of these children do not have these positive role models at home.' Even though this is mere conjecture on the preservice teacher's part, her statement exhibits a disposition that is concerned about the character development of her future students and their moral education.

We can see from these narratives that preservice teachers struggle for the right words to capture their moral concerns in regard to their teaching and their students' learning. Van Manen (2000) surmised, 'As educators are challenged to develop a moral vocabulary of teaching, such a language needs to be sensitive to the way that pedagogical relations are lived and experienced' (p. 315). This sensitivity is necessarily situated within the lived context of the particular educator's way of relating to his or her students. Similar to our efforts here regarding this disposition of moral education, Stooksberry, Schussler, and Bercaw (2009) took a sample of preservice teacher journaling for their discussion of three domains of dispositions (intellectual, cultural, and moral) 'to explore how teacher candidates are inclined to think through issues of content and pedagogy, the cultural backgrounds of their students, and the values

Reflective Practice, Vol 17, No. 2 (February 16, 2016): pg. 125-142. DOI. This article is @ Taylor \& Francis (Routledge) and permission has been granted for this version to appear in e-Publications@Marquette. Taylor \& Francis (Routledge) does not grant permission for this article to be further copied/distributed or hosted elsewhere without the express permission from Taylor \& Francis (Routledge). 
driving their moral reasoning' (p. 719). It is precisely in journaling about their own values that preservice teachers grapple with their disposition to teach moral and ethical values (Sockett, 2009).

\section{Individual freedom.}

Most of the preservice teachers grasped the importance of differentiation in teaching methods. Some of the participants expressed particular concern for the individual freedom of their students, which in turn reflected their own values of personal freedom as educators. One preservice teacher quite eloquently insisted, 'The idea of individual freedom also connects to modern classrooms in that students are treated as individuals with unique ways of learning rather than a homogenous group.' Other participants wrote about the interconnectedness between caring and respect for individual freedom when differentiating instruction. For example, one future educator avowed, 'I strongly agree with this idea tailoring your teaching to meet the needs of the individual children.' Another expressed it more indirectly by narrating, 'As a teacher, students need to understand that I care about each of them as an individual.' These preservice teachers viewed the disposition of individual freedom as essential if the teacher is to design lessons and use methodologies appropriate to the different personal and social contexts of students. Van Manen (2000), in addressing caring as a type of worrying, agreed with this same tendency of valuing of each student as a unique individual when he claimed, 'It is because a teacher feels addressed by the "faces" of particular students ...that the teacher can remain sensitive to the sometimes "faceless" multitude of all the other students for whom he or she is responsible' (p. 326).

\section{Implications and Recommendations}

In response to the first research question (Does reflective journaling help promote dispositional development in preservice teachers?), the data we have presented and analyzed above suggest that philosophy of education courses do provide an excellent platform for promoting reflective journaling as a means toward disposition development in preservice teachers. Indeed, as Russell (2005) insisted '...the question 'Can reflective practice be taught?' deserves the explicit

Reflective Practice, Vol 17, No. 2 (February 16, 2016): pg. 125-142. DOI. This article is (C) Taylor \& Francis (Routledge) and permission has been granted for this version to appear in e-Publications@Marquette. Taylor \& Francis (Routledge) does not grant permission for this article to be further copied/distributed or hosted elsewhere without the express permission from Taylor \& Francis (Routledge). 
attention of professional educators' (p. 200). The type of reflective journaling in the philosophy of education course under discussion is one such methodological approach to promote reflective practice.

Pedro (2005) posed the following question: '... what other forms of writing reflections can teacher educators use to teach pre-service teachers to critically reflect on their practice' (p. 63)? In response, we would recommend the use of reflective journaling not only as a medium to teach preservice teachers to critically reflect on their practice, but also as a way to enhance their practice (Chubbuck, 2010). In fact, one of the greatest challenges teacher educators face is how to assist preservice teachers to put their excellent theories into practice (Zeichner, 2010), and for that matter, how to actualize their dispositions (Chubbuck, 2010). Maintaining and enhancing selfreflective journaling over time in philosophy of education courses, as well as other foundational courses, help promote this critical, reflective process of linking theory with practice. We contend that this study has also aided preservice teacher programs by responding effectively to our second research question: What dispositions do preservice teachers self-identify in their reflective journaling? Furthermore, such self-reflective journaling in other courses might also serve as a means to develop, foster, and enhance appropriate dispositions in preservice teachers.

Further research is needed to determine if philosophy of education courses should be a requirement for preservice teachers in all programs, not just in Catholic colleges and universities. Based upon a department's or college's mission and vision, each institution will decide the appropriateness of a free-standing philosophy of education course. Even so, the data from this study suggest an added value beyond content knowledge in such philosophy of education courses: growth in dispositional awareness among preservice teaching through reflective journaling. Although the personal belief statements of preservice teachers in this study are laudable, they might be construed as rather naïve or even esoteric unless they are applied and tested in real classroom practice. Furthermore, because most students in the study were more likely to identify in themselves fairness rather than the belief that all students can learn (Table 2), we recommend that preservice teacher programs further cultivate and foster the

Reflective Practice, Vol 17, No. 2 (February 16, 2016): pg. 125-142. DOI. This article is (C) Taylor \& Francis (Routledge) and permission has been granted for this version to appear in e-Publications@Marquette. Taylor \& Francis (Routledge) does not grant permission for this article to be further copied/distributed or hosted elsewhere without the express permission from Taylor \& Francis (Routledge). 
development of culturally diverse and inclusive perspectives in their licensure candidates. Additional research is needed to review preservice teacher programs in public and non-Catholic colleges and universities to determine how prevalently they require philosophy of education and, if so, do these courses promote dispositional development through reflective journaling or other methods.

In addition, we would recommend that preservice teacher education programs broaden their expectations for dispositional growth among preservice teachers to move beyond the essential NCATE (2009) dispositions of fairness and the belief that all students can learn, to include additional dispositions evidenced in this study and others, as well as those identified in the particular department's or institution's mission and vision statements. A closer look at the particular wording of the indicators under Principle 3 of the InTASC (2011) Standards for Teacher Development and Licensure might prove useful in this regard:

9.21 The teacher values critical thinking and self-directed learning as habits of mind.

9.22 The teacher is committed to reflection, assessment, and learning as an ongoing process.

9.23 The teacher is willing to give and receive help.

9.24 The teacher is committed to seeking out, developing, and continually refining practices that address the individual needs of students.

9.25 The teacher recognizes his/her professional responsibility for engaging in and supporting appropriate professional practices for self and colleagues. (p. 10)

All of these indicators support the types of other dispositions selfidentified in this study and are worthy of additional consideration by preservice teacher programs. Furthermore, reflective journaling through coursework and portfolios provides an excellent opportunity to assess preservice teacher dispositional growth. One particularly appropriate course for such reflective journaling is the philosophy of education. The recent CAEP (2013) accreditation standards have also stressed the important responsibility of preservice teacher programs '...to ensure the quality of their candidates. This responsibility continues from purposeful recruitment...through monitoring of 
candidate progress and providing necessary support, to demonstrating that candidates are proficient at completion...' (p. 10).

The challenge facing teacher preparation programs in this regard is the development of instruments which will effectively measure this growth. To that end, another area of needed research generated through this study is how to measure the growth of preservice teacher dispositions across time in teacher preparation programs. The CAEP (2013) further elucidated on this need when they asserted, that '...there does not seem to be a clear measure for these non-academic qualities, although a few of them have scales and other measures that have been developed' (p. 11). The Council goes on to acknowledge 'the ongoing development of this knowledge base and recommends that CAEP revise criteria as evidence emerges' (CAEP, 2013, p. 11). To that end, although this study, in a small way, has contributed to this effort, further metrics need to be developed to more accurately measure dispositional growth and how such dispositions are actualized in classroom practice.

Finally, a number of questions were identified during the process of reviewing the results of this study which point to the need for further research: Does this process of reflective journaling lead the preservice teacher toward different dispositions that build upon the two NCATE (now CAEP) dispositions? Does this process of reflective journaling lead the preservice teacher toward dispositional growth beyond the two NCATE (now CAEP) dispositions? Does the growth suggested in this study (from fairness and belief to openness, empowerment, caring, and relationship) support Chubbuck's (2010) study? To what extent do preservice teachers translate these selfidentified dispositions into actual classroom practice?

Over thirty years ago, Tom (1984) conceptualized teacher education as a moral craft, with implications for integrating theory and practice. In contrast to an applied science model, Tom (1984) proposed a moral craft metaphor because it '...suggests a more interactive relationship between knowledge and practice. After all, a craft is something one learns by engaging concurrently in the craft and analyzing the results of this engagement' (p. 321). Our findings support such a conceptualization of teacher education, a moral craft

Reflective Practice, Vol 17, No. 2 (February 16, 2016): pg. 125-142. DOI. This article is (C) Taylor \& Francis (Routledge) and permission has been granted for this version to appear in e-Publications@Marquette. Taylor \& Francis (Routledge) does not grant permission for this article to be further copied/distributed or hosted elsewhere without the express permission from Taylor \& Francis (Routledge). 
NOT THE PUBLISHED VERSION; this is the author's final, peer-reviewed manuscript. The published version may be accessed by following the link in the citation at the bottom of the page.

that seeks to encourage reflective journaling as a means to promote disposition development and assist preservice teachers to grasp the complexity and interconnectedness of theory with classroom practice.

\section{References}

Banks, J., \& McGhee Banks, C. A. (Eds.) (2010). Multicultural education: Issues and perspectives ( $7^{\text {th }}$ ed.). Hoboken, $\mathrm{NJ}$ : John Wiley \& Sons, Inc.

Bogdan, R. C., \& Biklen, S. K. (1998). Qualitative research for education: An introduction to theory and methods ( $3^{\text {rd }}$ ed.). Boston, MA: Allyn and Bacon.

Borko, H., Michalec, P., Timmons, M., \& Siddle, J. (1997). Student teaching portfolios: A tool for promoting reflective practice. Journal of Teacher Education, 48(5), 345-357.

Borko, H., Liston, D., \& Whitcomb, J. A. (2007). Apples and fishes: The debate over dispositions in teacher education. Journal of Teacher Education, 58(5), 359-364.

Burant, T. J., Chubbuck, S. M., \& Whipp, J. L. (2007). Reclaiming the moral in the dispositions debate. Journal of Teacher Education, 58(5), 397-411.

Chubbuck, S. M. (2010). Individual and structural orientations in socially just teaching: Conceptualization, implementation, and collaborative effort. Journal of Teacher Education, 61(3), 197-210.

Clarà, M. (2015). What is reflection? Looking for clarity in an ambiguous notion. Journal of Teacher Education 66(3), 261-271.

Council for the Accreditation of Educator Preparation (CAEP). (2013). CAEP 2013 standards for accreditation of educator preparation. Retrieved April 10, 2014, from http://caepnet.files.wordpress.com/2013/09/final_board_approved1.p df

Damon, W. (2007). Dispositions and teacher assessment: The need for a more rigorous definition. Journal of Teacher Education, 58(5), 365369.

Delpit, L. (2006). Other people's children: Cultural conflict in the classroom. New York, NY: The New Press.

Dewey, J. (1974). Why reflective thinking must be an educational aim. In R. D. Archambault, (Ed.), John Dewey, on education: Selected writings (pp. 212-228). Chicago, IL: University of Chicago Press.

Diez, M. (2007). Looking back and moving forward: Three tensions in the teacher dispositions discourse. Journal of Teacher Education, 58(5), 388-396.

Reflective Practice, Vol 17, No. 2 (February 16, 2016): pg. 125-142. DOI. This article is (C) Taylor \& Francis (Routledge) and permission has been granted for this version to appear in e-Publications@Marquette. Taylor \& Francis (Routledge) does not grant permission for this article to be further copied/distributed or hosted elsewhere without the express permission from Taylor \& Francis (Routledge). 
NOT THE PUBLISHED VERSION; this is the author's final, peer-reviewed manuscript. The published version may be accessed by following the link in the citation at the bottom of the page.

Freese, A. R. (1999). The role of reflection on preservice teachers' development in the context of a professional development school. Teaching and Teacher Education. 15(8), 895-909.

Freese, A. R. (2006). Reframing one's teaching: Discovering our teacher selves through reflection and inquiry. Teaching and Teacher Education, 22(1), 100-119.

Freire, P. (2001). Pedagogy of freedom: Ethics, democracy, and civic courage. Lanham, MD: Rowman \& Littlefield Publishers.

Gall, J. P., Gall, M. D., \& Borg, W. R. (1999). Applying educational research: A practical guide ( $4^{\text {th }}$ ed.). New York, NY: Longman.

Gay, G. (2010). Culturally responsive teaching: Theory, research, and practice $\left(2^{\text {nd }}\right.$ ed.). New York, NY: Teachers College Press.

Ghaye, T., Melander-Wikman, A., Kisare, M., Chambers, P., Bergmark, U., Kostenius, C, \& Lillyman, S. (2008). Participatory and appreciative action and reflection (PAAR) - democratizing reflective practices. Reflective Practice 9(4), 361-397.Gosselin, C. (2007). Philosophy and the role of teacher reflections on constructing gender. Educational Foundations, 21(3/4), 39-57.

Hatton, N., \& Smith, D. (1995). Reflection in teacher education: Towards definition and implementation. Teaching and Teacher Education, 11(1) 33-49.

InTASC. (2011). Interstate Teacher Assessment and Support Consortium (InTASC) core standards, Retrieved October 25, 2012, from

http://www.ecu.edu/cs-educ/teached/upload/INTASCStandardsIndicators.pdf

Irvine, J. J. (2012). Complex relationship between multicultural education and special education: An African American perspective. Journal of Teacher Education, 63(4), 268-274.

Korthagen, F. A., \& Wubbels, T. (1996). Characteristics of reflective practitioners: Towards an operationalization of the concept of reflection. Teacher and Teaching: Theory and Practice, 1(1), 51-72.

Larrivee, B. (2000). Transforming teaching practice: Becoming the critically reflective teacher. Reflective Practice, 1(3), 293-307.

Lieblich, A., Zilber, T. R., \& Tuval-Mashiach, R. (1998). Narrative research. Thousand Oaks, CA: SAGE Publications, Inc.

Loughran, J. J. (2002). Effective reflective practice: In search of meaning in learning about teaching. Journal of Teacher Education, 53(1), 33-43.

Mayeroff, M. (1971). On caring (Vol. 43). New York, NY: Harper \& Row.

Mucci, A. M., \& Cranston-Gingras, A. (2011). A foundation for reflection and questioning: Philosophy course requirements in teacher education programs at selected Catholic colleges and universities. Catholic Education: A Journal of Inquiry and Practice, 14(4), 371-390.

National Council for Accreditation of Teacher Education. (NCATE). (2006). Professional standards for the accreditation of schools, colleges, and

Reflective Practice, Vol 17, No. 2 (February 16, 2016): pg. 125-142. DOI. This article is (C) Taylor \& Francis (Routledge) and permission has been granted for this version to appear in e-Publications@Marquette. Taylor \& Francis (Routledge) does not grant permission for this article to be further copied/distributed or hosted elsewhere without the express permission from Taylor \& Francis (Routledge). 
NOT THE PUBLISHED VERSION; this is the author's final, peer-reviewed manuscript. The published version may be accessed by following the link in the citation at the bottom of the page.

departments of education, 2006 edition. Retrieved July 11, 2007, from http://www.ncate.org/institutions/standards.asp?ch $=4$

National Council for Accreditation of Teacher Education. (NCATE). (2008). Professional standards for the accreditation of teacher preparation institutions, 2008 edition. Retrieved October 22, 2012, from http://www.ncate.org/Portals/0/documents/Standards/NCATE\%20Stan dards\%202008.pdf

Noddings, N. (1984). Caring: A feminine approach to ethics and moral education. Berkeley, CA: University of California Press.

Noddings, N. (2012). Philosophy of education ( $3^{\text {rd }}$ ed.). Boulder, CO: Westview Press.

Oner, D., \& Adadan, E. (2011). Use of web-based portfolios as tools for reflection in preservice teacher education, Journal of Teacher Education, 62(5), 477-492.

Pedro, J. Y. (2005). Reflection in teacher education: Exploring pre-service teachers' meanings of reflective practice. Reflective Practice, 6(1), 4966.

Rodgers, C. (2002). Defining reflection: Another look at John Dewey and reflective thinking. Teachers College Record, 104(4), 842-866.

Russell, T. (2005). Can reflective practice be taught? Reflective Practice 6(2), 199-204.

Schussler, D. L., Stooksberry, L. M., \& Bercaw, L. A. (2010). Understanding teacher candidate dispositions: Reflecting to build self-awareness, Journal of Teacher Education, 61(4), 350-363.

Smyth, J. (1989). Developing and sustaining critical reflection in teacher education. Journal of Teacher Education, 40(2), 2-9.

Sockett, H. (2006). Character, rules, and relations. In H. Sockett (Ed.), Teacher dispositions: Building a teacher education framework of moral standards (pp. 8-25). Washington, DC: AACTE.

Sockett, H. (2009). Dispositions as virtues: The complexity of the construct. Journal of Teacher Education, 60(3), 291-303.

Stooksberry, L. M., Schussler, D. L., \& Bercaw, L. A. (2009). Conceptualizing dispositions: Intellectual, cultural and moral domains of teaching. Teachers and Teaching: Theory and Practice, 15(6), 719-736.

Tom, A. R. (1980). Teaching as a moral craft. Curriculum Inquiry, 10(3), 317323.

Van Manen, M. (2000). Moral language and pedagogical experience. Journal of Curriculum Studies, 32(2), 315-327.

Villegas, A. M. (2007). Dispositions in teacher education: A look at social justice. Journal of Teacher Education, 58(5), 370-380.

Wade, R. (1996). Portfolios: A tool for reflective thinking in teacher education? Teaching \& Teacher Education, 12(1) 63-79.

Reflective Practice, Vol 17, No. 2 (February 16, 2016): pg. 125-142. DOI. This article is (C) Taylor \& Francis (Routledge) and permission has been granted for this version to appear in e-Publications@Marquette. Taylor \& Francis (Routledge) does not grant permission for this article to be further copied/distributed or hosted elsewhere without the express permission from Taylor \& Francis (Routledge). 
Zeichner, K. M., \& Liston, D. P. (1996). Reflective teaching: An introduction. Mahwah, NJ: Lawrence Erlbaum Associates.

Zeichner, K. M. (2010). Rethinking the connections between campus courses and field experiences in college- and university-based teacher education. Journal of Teacher Education, 61(1-2), 89-99.

\section{Appendix Reflective Journaling Prompts}

\section{Journal 1}

Write a 500-word (about two-page) reflection on how educational philosophies before the 20th century have influenced your personal approach to or perspective on education. Include theories and examples of how they can be applied to the classroom in which you envision yourself teaching.

Some questions that may help guide your writing can be found on page 22 of Nel Noddings' Philosophy of Education.

\section{Journal 2}

Write a 500-word (about a two-page, double-spaced Word document) reflection on how modern educational philosophies can be applied to classroom practice today. Discuss how individual freedom, political viewpoints, culture, and literacy impact American education in the 21st century. Show how these theories can be put into practice in the classroom in which you envision yourself teaching. You may draw some ideas from pp. 23-60 of Nel Noddings' Philosophy of Education.

\section{Journal 3}

Write a 500-word (about a two-page, double-spaced Word document) reflection on how you would apply postmodern and existential philosophical theories (such as Jean Paul Sartre or Maxine Greene) to the classroom in which you envision yourself teaching. Discuss how issues of personal freedom, meaning making, and globalization affect your approach to teaching and learning.

You may draw some ideas from pp. 61-106 of Nel Noddings' Philosophy of Education.

Reflective Practice, Vol 17, No. 2 (February 16, 2016): pg. 125-142. DOI. This article is (C) Taylor \& Francis (Routledge) and permission has been granted for this version to appear in e-Publications@Marquette. Taylor \& Francis (Routledge) does not grant permission for this article to be further copied/distributed or hosted elsewhere without the express permission from Taylor \& Francis (Routledge). 
NOT THE PUBLISHED VERSION; this is the author's final, peer-reviewed manuscript. The published version may be accessed by following the link in the citation at the bottom of the page.

\section{Journal 4}

Write a 500-word (about a two-page, double-spaced Word document) critical reflection on your experience of the knowing and learning process among children and adolescents. Draw from your own personal experience, Piaget's developmental theories, or other educational theorists.

\section{Journal 5}

Write a 500-word (about a two-page, double-spaced Word document) reflection on how you would apply critical pedagogical theories in the classroom in which you envision yourself teaching. You may draw some ideas from Freire's Pedagogy of Freedom or pp. 177-197 of Nel Noddings' Philosophy of Education. 